\title{
Taste, terroir, and technology
}

This article was published in the following Dove Press journal:

International Journal of Wine Research

I5 March 2016

Number of times this article has been viewed

\section{Roger M Pinder}

International Journal of Wine Research, York, UK
Correspondence: Roger M Pinder

2 St Wilfrid's Court, York YO3I 7UQ, UK

$\mathrm{Tel}+441904646684$

Email roger.pinder@gmail.com
Wine drinkers have long acknowledged the link between taste and terroir, the often unmistakable connection between the flavor of a wine and the particular patch of ground in which the vines were grown. But the science behind the connection, indeed the whole concept of taste and terroir, has long been disputed. New technological developments in both "neuroenology" - how the brain creates the taste of wine ${ }^{1}$ - and in wine chemistry ${ }^{2}$ have offered more insight into the science.

Researchers from the University of California at Davis, a renowned center for wine science, compared the composition and taste of Malbec wines from 26 sites in Mendoza, Argentina, and 15 sites in California, USA. ${ }^{2}$ The wines from both countries were all made using standardized vinification methods and they underwent the same duration of ageing. Oak, acidification, and filtration were not used. The composition of the various wines was analyzed by modern technology including gas chromatographymass spectrometry and selected ion monitoring. Tasting was performed by a panel of judges at the University of California at Davis wine sensory laboratory, who employed 35 descriptive characteristics to define the flavor of the wines. Direct relationships between certain chemical components and flavors were clearly identified; "red fruit" was associated with $\alpha$-terpinene, limonene, and $\alpha$-pinene, while spicy characteristics were linked with eugenol and 4-methylguaiacol. Overall, the various Malbec wines were clearly separated by wine region and country, based on their chemical and sensory profiles, although common features included aromas of cooked vegetal, earthy, soy, volatile acidity, acidic taste, and astringent mouthfeel. Mendozan Malbec generally had more ripe fruit, sweetness, and higher alcohol levels, while that from California had more artificial fruit and citrus aromas as well as a bitter taste. Differences in chemical composition between Mendozan wines and those from California were related more to altitude than to precipitation or growing degree days, while rootstock, vine age, and trellising systems had negligible influence. Californian terroir was clearly different from that in Mendoza, both on chemical and sensory grounds, but interregional differences were smaller.

Subsequent research by the same group ${ }^{3}$ has suggested, however, that winery processing may sometimes be combined with vineyard origin to determine the elemental chemical pattern of many wines. Thus, when analyzing 65 red wine samples from five different vineyards within 40 miles of each other processed in at least two separate wineries, the group found that both vineyard origin and winery processing have an impact on chemical composition of the wines, but each vineyard and each winery

Dovepress

(c) (1) (5) 2016 Pinder. This work is published and licensed by Dove Medical Press Limited. The full terms of this license are available at https://www.dovepress.com/terms.php BY NG and incorporate the Creative Commons Attribution - Non Commercial (unported, v3.0) License (http://creativecommons.org/licenses/by-nc/3.0/). By accessing the work you
hereby accept the Terms. Non-commercial uses of the work are permitted without any further permission from Dove Medical Press Limited, provided the work is properly attributed. For permission for commercial use of this work, please see paragraphs 4.2 and 5 of our Terms (https://www.dovepress.com/terms.php). 
altered the composition in different ways. Wine from some vineyards showed a characteristic elemental pattern wherever the grapes were processed, while some wineries produced identical chemical compositions in wines independent of the origin of the vineyard.

So if terroir is not yet an entirely settled issue in scientific terms, what about the way the flavors of wine are actually perceived? It may be that flavor is not in the food or wine at all, but is created from the food or wine in the brain. ${ }^{4}$ Indeed, the multiple neural mechanisms involved in producing flavor may include sensory, motor, cognitive, emotional, language, pre- and post-ingestive, hormonal, and metabolic aspects. ${ }^{1}$ The successive stages of anticipation, biomechanical movement of the ingested wine, and transport of the released volatile elements correlate with multiple brain mechanisms. The stages include the initial anticipatory or cephalic phase, visual analysis, ingestion, formation of a perceptual image of the wine, formation of the wine as a perceptual object, swallowing, and post-ingestion effects. Terroir, if it exists, may be all in the mind.
Therefore, the jury is still out on whether terroir is real or is based on (mis)perception. The chemical composition of wines may be determined by the ground in which the vines are grown and by additional factors such as altitude of the vineyard, but the way that the grapes are processed may in some cases lay its own signature over any vineyard differences. And taste may be only about perception, with all of its foibles. As in many research papers, we have to conclude "more research is needed".

\section{Disclosure}

The author reports no conflicts of interests in this work.

\section{References}

1. Shepherd GM. Neuroenology: how the brain creates the taste of wine. Flavour. 2015;4:19-23.

2. King ES, Stoumen M, Buscema F, et al. Regional sensory and chemical characteristics of Malbec wines from Mendoza and California. Food Chem. 2014;143:256-267.

3. Hopfer H, Nelson J, Collins TS, Heymann H, Ebeler SE. The combined impact of vineyard origin and processing winery on the elemental profile of red wines. Food Chem. 2015;172:486-496.

4. Small DM. Flavor is in the brain. Physiol Behav. 2012;107(4): $540-552$.

Dove Medical Press encourages responsible, free and frank academic debate. The content of the International Journal of Wine Research 'Editorial' section does not necessarily represent the views of Dove Medical Press, its officers, agents, employees, related entities or the International Journal of Wine Research editors. While all reasonable steps have been taken to confirm the content of each Editorial, Dove Medical Press accepts no liability in respect of the content of any Editorial, nor is it responsible for the content and accuracy of any Editorial.

\section{Publish your work in this journal}

The International Journal of Wine Research is an international, peer-reviewed open-access, online journal focusing on all scientific aspects of wine, including: vine growing; wine elaboration; human interaction with wine; and health aspects of wine. The journal provides an open access platform for the reporting of evidence based studies on these topics. The manuscript management system is completely online and includes a very quick and fair peer-review system, which is all easy to use. Visit http://www.dovepress.com/testimonials.php to read real quotes from some of our published authors. 